\title{
Epidemiologi Tuberkulosis
}

\author{
Cissy B. Kartasasmita \\ Bagian Ilmu Kesehatan Anak FK Universitas Padjadjaran/RS Hasan Sadikin, Bandung
}

\begin{abstract}
Tuberkulosis (TB) masih merupakan penyebab utama morbiditas dan mortalitas pada anak di dunia, namun kurang mendapat prioritas dalam penanggulangannya. Data surveilans dan epidemiologi TB pada anak jarang didapat. Hal ini disebabkan berbagai faktor antara lain sulitnya diagnosis TB anak, meningkatnya TB ekstra paru pada anak, tidak adanya standar baku definisi kasus, dan prioritas yang kurang diberikan pada TB anak di banding TB dewasa. Berbagai penelitian menunjukkan prevalensi TB anak tinggi, namun umumnya tanpa konfirmasi pemeriksaan bakteri tahan asam (BTA) positif. Salah satu indikator untuk menilai situasi TB di komunitas adalah dengan Annual Risk of Tuberculosis Infection (ARTI), adalah indeks epidemiologi yang dipakai untuk evaluasi dan monitor keadaan tuberkulosis di suatu komunitas atau negara. Perbedaan angka morbiditas dan mortalitas TB di berbagai negara dipengaruhi oleh beberapa faktor risiko, dibedakan antara risiko infeksi TB dan sakit TB. (Sari Pediatri 2009;11(2):124-9).
\end{abstract}

Kata kunci: morbiditas, mortalitas, ARTI, uji tuberkulin, faktor risiko

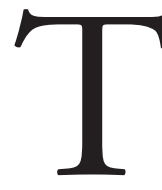

uberkulosis masih merupakan penyakit penting sebagai penyebab morbiditas dan mortalitas, dan tingginya biaya kesehatan Setiap tahun diperkirakan 9 juta kasus TB baru dan 2 juta di antaranya meninggal. Dari 9 juta kasus baru TB di seluruh dunia, 1 juta adalah anak usia $<15$ tahun. Dari seluruh kasus anak dengan TB, 75\% didapatkan di duapuluh dua negara dengan beban TB tinggi (high burden countries). Dilaporkan dari berbagai negara presentase semua kasus TB pada anak berkisar antara 3\% sampai $>25 \%$. ${ }^{1,2}$

Mayoritas anak tertular TB dari pasien TB dewasa, sehingga dalam penanggulangan $\mathrm{TB}$ anak, penting untuk

\footnotetext{
Alamat korespondensi

Prof. DR. Dr Cissy B. Kartasasmita, Sp.A(K) Bagian/UPF Ilmu Kesehatan Anak FKUP/RSUP dr. Hasan Sadikin Jl. Pasteur No. 38 Telepon./Fax. 2034426-203595 Bandung 40161
}

mengerti gambaran epidemiologi TB pada dewasa. Infeksi TB pada anak dan pasien TB anak terjadi akibat kontak dengan orang dewasa sakit TB aktif. Diagnosis TB pada dewasa mudah ditegakkan dari pemeriksaan sputum yang positif. Sulitnya konfirmasi diagnosis TB pada anak mengakibatkan penanganan TB anak terabaikan, sehingga sampai beberapa tahun TB anak tidak termasuk prioritas kesehatan masyarakat di banyak negara, termasuk Indonesia. Akan tetapi beberapa tahun terakhir dengan penelitian yang dilakukan di negara berkembang, penanggulangan TB anak mendapat cukup perhatian. Dari beberapa negara Afrika dilaporkan hasil isolasi Mycobacterium tuberculosis (MTB) 7\%-8\% pada anak yang dirawat dengan pneumonia berat akut dengan dan tanpa infeksi human immunodeficiency virus (HIV), dan TB merupakan penyebab kematian pada kelompok anak tersebut. ${ }^{3,4,5}$ Dilaporkan juga dari Afrika Selatan bahwa pada anak anak yang sakit TB didapatkan prevalensi HIV $40 \%-50 \% .^{6,7}$ 
Masalah yang dihadapi saat ini adalah meningkatnya kasus TB dengan pesat selain karena peningkatan kasus penyakit HIV/AIDS juga meningkatnya kasus multidrug resistence-TB (MDR-TB), hasil penelitian di Jakarta mendapatkan $>4 \%$ dari kasus baru. Masalah lain adalah peran vaksinasi BCG dalam pencegahan infeksi dan penyakit TB yang masih kontroversial. Berbagai penelitian melaporkan proteksi dari vaksinasi BCG untuk pencegahan penyakit TB berkisar antara $0 \%-80 \%$, secara umum diperkirakan daya proteksi BCG hanya 50\%, dan vaksinasi BCG hanya mencegah terjadinya TB berat, seperti milier dan meningitis TB. Daya proteksi BCG terhadap meningitis TB 64\%, dan miler TB 78\% pada anak yang mendapat vaksinasi. ${ }^{8}$

Salah satu metode untuk estimasi insidensi TB dan evaluasi TB di komunitas atau di suatu negara dilakukan dengan menilai ARTI (annual risk of tubeculosis infections) di populasi umum. Nilai ARTI menggambarkan proporsi individu di komunitas yang berpeluang terinfeksi atau terinfeksi ulang dalam kurun waktu satu tahun, diperkirakan dari hasil survei uji tuberkulin di populasi umum. ${ }^{8}$ Dilain pihak, ARTI merupakan indikator transmisi di komunitas yang bergantung pada prevalensi kasus TB yang infeksius dan efikasi dari aktivitas pengendalian TB seperti penemuan kasus (case finding) dan pengobatan.'

Untuk menilai faktor risiko harus dibedakan antara infeksi TB dan sakit TB. Risiko infeksi TB tergantung pada lamanya terpajan, kedekatan dengan kasus TB, dan beban kuman pada kasus sumber. Risiko tinggi untuk sakit TB antara lain umur kurang dari 5 tahun (balita), malnutritisi, infeksi TB baru, dan imunosupresi terutama karena HIV.,

\section{Morbiditas dan mortalitas}

Menurut WHO sepertiga penduduk dunia telah tertular TB, tahun 2000 lebih dari 8 juta penduduk dunia menderita TB aktif. Penyakit TB bertanggung jawab terhadap kematian hampir 2 juta penduduk setiap tahun, sebagian besar terjadi di negara berkembang. World Health Organization memperkirakan bahwa TB merupakan penyakit infeksi yang paling banyak menyebabkan kematian pada anak dan orang dewasa. Kematian akibat TB lebih banyak daripada kematian akibat malaria dan AIDS. Pada wanita kematian akibat TB lebih banyak dari pada kematian karena kehamilan, persalinan, dan nifas. Menurut perkiraan antara tahun 2000-2020 kematian karena TB meningkat sampai 35 juta orang. Setiap hari ditemukan 23.000 kasus TB aktif dan TB menyebabkan hampir 5000 kematian. Total insidens TB selama 10 tahun, dari tahun 19901999 diperkirakan 88,2 juta dan 8 juta di antaranya berhubungan dengan infeksi HIV. Pada tahun 2000 terdapat 1,8 juta kematian akibat TB 226.000 di antaranya berhubungan dengan HIV. ${ }^{1,2}$

Setiap tahun didapatkan 250.000 kasus TB baru di Indonesia dan kira-kira 100.000 kematian karena TB. Tuberkulosis merupakan penyebab kematian nomor satu diantara penyakit infeksi dan menduduki tempat ketiga sebagai penyebab kematian pada semua umur setelah penyakit kardiovaskuler dan penyakit infeksi saluran napas akut. Pasien TB di Indonesia terutama berusia antara 15-5 tahun, merupakan kelompok usia produktif. Menurut perkiraan WHO pada tahun 1999, jumlah kasus TB baru di Indonesia 583.000 orang per tahun dan menyebabkan kematian sekitar 140.000 orang per tahun. ${ }^{10,11}$

Tahun 1989, WHO memperkirakan jumlah kasus baru TB 1,3 juta kasus dan 450.000 kematian karena TB pada anak usia $<15$ tahun di dunia. ${ }^{12}$ Tahun 1994 diperkirakan insidensi global TB pada anak usia 0-14 tahun akan mencapai 1 juta kasus di tahun 2000, setengah dari jumlah kasus tersebut berada di Afrika. Berarti ada peningkatan 36\% dari perkiraan tahun 1990. ${ }^{13}$ Pada tahun 1990, jumlah kematian karena TB di dunia diperkirakan hampir 3 juta dan hampir 90\% kematian tersebut terjadi di negara berkembang. Pada tahun 2000 jumlah kematian diperkirakan 3,5 juta, kasus baru meningkat setiap tahun. Pada tahun 1990 dilaporkan 7,5 juta kasus (143 kasus per 100.000 penduduk) menjadi 8,8 juta kasus (152 kasus per 100.000 penduduk) pada tahun $1995,10,2$ juta kasus (163 kasus per 100.000 penduduk) pada tahun 2000, dan mencapai 11,9 juta kasus pada tahun 2005. ${ }^{1,2}$

Di negara berkembang, TB pada anak berusia $<15$ tahun adalah $15 \%$ dari seluruh kasus TB, sedangkan di negara maju, lebih rendah yaitu 5\%-7\%. Pada survei nasional di Inggris dan Wales yang berlangsung selama setahun pada tahun 1983, didapatkan bahwa 452 anak berusia $<15$ tahun menderita TB. ${ }^{14}$ Laporan mengenai TB anak di Indonesia jarang didapatkan, diperkirakan jumlah kasus TB anak adalah 5\%-6\% dari total kasus TB. Berdasarkan laporan tahun 1985, dari 1261 kasus TB anak berusia $<15$ tahun, 63\% di antaranya berusia $<5$ tahun. Hasil penelitian di dua kecamatan di Kotamadya Bandung tahun 1999-2001, 
didapatkan 4,3\% (63/1482) anak usia 6-59 bulan, menderita TB. ${ }^{15}$ Data seluruh kasus TB anak dari tujuh rumah sakit Pusat Pendidikan Indonesia selama 5 tahun (1998-2002) dijumpai 1086 kasus TB dengan angka kematian bervariasi dari $0 \%-14,1 \%$. Kelompok usia terbanyak $12-60$ bulan (42,9\%), sedangkan bayi $<12$ bulan didapatkan 16,5\%. ${ }^{16}$ Laporan hasil Riset Kesehatan Dasar (Riskesdas) tahun 2007, didapatkan prevalensi 12 bulan TB paru klinis di Indonesia 1\% dengan kisaran 0,3\% (Lampung) sampai 2,5\% (Papua). Berdasarkan kelompok umur dijumpai prevalensi TB, kurang dari 1 tahun $0,47 \%, 1-4$ tahun $0,76 \%$ dan antara 5-14 tahun 0,53\%. ${ }^{16}$

Selama tahun 1985-1992, peningkatan TB paling banyak terjadi pada usia 25-44 tahun $(54,5 \%)$, diikuti oleh usia $0-4$ tahun $(36,1 \%)$, dan 5-12 tahun $(38,1 \%)$. Pada tahun 2005, diperkirakan kasus TB naik 58\% dari tahun 1990, 90\% di antaranya terjadi di negara berkembang. Di Amerika Serikat dan Kanada, peningkatan TB pada anak berusia 0-4 tahun 19\%, sedangkan pada usia 5-15 tahun 40\%. Di Asia Tenggara selama 10 tahun, diperkirakan jumlah kasus baru 35,1 juta, 8\% di antaranya (2,8 juta) disertai infeksi HIV. Menurut WHO (1994), Indonesia menduduki peringkat ketiga dalam jumlah kasus baru TB (0,4 juta kasus baru), setelah India (2,1 juta kasus) dan Cina (1,1 juta kasus), 10\% dari seluruh kasus terjadi pada anak berusia $<15$ tahun. ${ }^{18,19}$

Peningkatan jumlah kasus TB di berbagai tempat pada saat ini, diduga disebabkan oleh berbagai hal, yaitu (1) diagnosis tidak tepat, (2) pengobatan tidak adekuat,

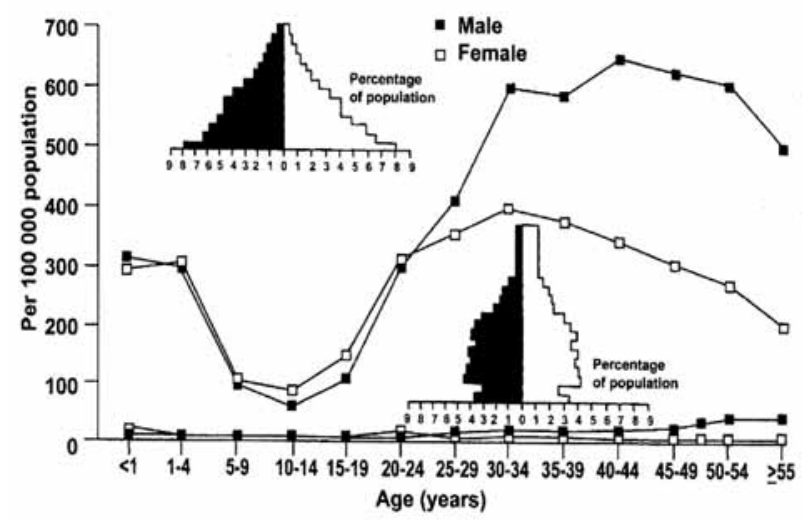

Gambar 1. Jumlah populasi berdasarkan usia di negara berkembang

Sumber: Peter R Donald. ${ }^{20}$
(3) program penanggulangan tidak dilaksanakan dengan tepat, (4) infeksi endemik HIV, (5) migrasi penduduk, (6) mengobati sendiri (self treatment), (7) meningkatnya kemiskinan, dan (8) pelayanan kesehatan yang kurang memadai. Tuberkulosis anak merupakan faktor penting di negara berkembang karena jumlah anak berusia $<15$ tahun adalah $40 \%$ $50 \%$ dari jumlah seluruh populasi (Gambar 1).

Sulitnya menegakkan diagnosis TB pada anak, maka data TB anak sangat terbatas termasuk di Indonesia. Untuk mengatasi kesulitan tersebut, WHO sedang melakukan upaya dengan cara membuat konsensus diagnosis di berbagai negara. Dengan adanya konsensus TB, diharapkan diagnosis TB anak dapat ditegakkan, sehingga kemungkinan overdiagnosis atau underdiagnosis dapat diperkecil dan angka prevalens pasti dapat diketahui.

\section{Prevalens tuberkulin positif}

Uji tuberkulin adalah uji yang dilakukan untuk mendeteksi infeksi M. tuberkulosis, dapat juga dipergunakan untuk mengukur prevalens infeksi. Dari prevalens infeksi dapat diketahui annual risk of tuberculosis infections (ARTI) dengan metode konversi, dan merupakan salah satu parameter epidemiologi untuk menentukan beban penyakit (burden of tuberculosis). Parameter epidemiologi lainnya adalah perkiraan insidens BTA positif pada proses TB paru, kasus yang dilaporkan dan laju yang dilaporkan (case notificationsnotification rates), perkiraan cakupan yang mendapat layanan kesehatan di populasi, serta perkiraan case fatality rate untuk pasien dengan BTA positif dan TB yang lain. Nilai ARTI adalah probabilitas seseorang yang tidak terinfeksi menjadi terinfeksi atau re-infeksi oleh M. tuberkulosis, dalam kurun waktu satu tahun; dapat diperkirakan bila dilakukan survei tuberkullin berulang di suatu populasi pada waktu yang berbeda. Survei tersebut dilaksanakan dengan teknik yang sama, pada sekelompok subjek yang belum mendapat vaksinasi BCG dengan usia yang sama, sehinggga dilaksanakan pada anak tanpa skar BCG saja. Namun akhir-akhir ini karena tingginya cakupan imunisasi BCG, jumlah anak yang tidak mempunyai skar BCG terbatas, sehingga diikutsertakan pula anak yang telah diimunisasi BCG (skar BCG positif). ${ }^{11,21}$

Bila sistem surveilans tidak dapat dilakukan untuk deteksi dan pelaporan insidensi kasus, 
Cissy B. Kartasasmita: Epidemiologi tuberkulosis

maka ARTI merupakan teknik yang dapat dipertanggungjawabkan untuk mengetahui besarnya infeksi TB. Berdasarkan survei yang dilakukan pada tahun 2004 . rata-rata prevalensi kasus BTA positif diperkirakan 104 per 100.000 penduduk. Namun dengan membaginya berdasarkan durasi penyakit, insiden dari kasus BTA positif menjadi 96 per 100.000 penduduk. Hasil penelitian uji tuberkulin di beberapa negara berkembang telah dipakai untuk memperkirakan besarnya ARTI. Dengan dasar survei uji tuberkulin pada anak, diperkirakan ARTI di negara berkembang berkisar antara $0,6 \%$ sampai $2,3 \%$. Data ARTI di negara-negara Afrika daerah Sub-Sahara berkisar antara 1,5\% sampai 2,5\%, disusul oleh negara-negara Asia Selatan dan dan Asia Timur sebesar $1 \%$ sampai $2 \%$, sedangkan di Afrika Utara, Timur Tengah dan Amerika Tengah dan Latin, ARTI diperkirakan antara $0,5 \%$ dan 1,5\%.

Beberapa penelitian mengenai ARTI telah dilakukan di India. Penelitian di Bangalore, India tahun 20052006, pada 2459 anak usia 5-14 tahun dilakukan uji tuberkulin pada 2235 anak hasil tes dapat dibaca; proporsi skar BCG positif $63,7 \%$. Selanjutnya dilaporkan bahwa prevalensi terduga infeksi TB 5,8\% dengan ARTI $0,6 \%$ dari prevalensi terduga. Sebagai perbandingan hasil penelitian di Bangalore tahun 1990-1994 didapatkan penurunan ARTI 3\% setiap tahun. ${ }^{22}$ Gopi dkk (2006) melaporkan hasil penelitiannya di sub-distrik Tiruvaller, India Selatan setelah diimplementasikan program DOTS. Dari tiga survei didapatkan penurunan bermakna ARTI masing-masing 1,6\% tahun 1999-20021, 1,4\% tahun 2001-2003, dan 1,2\% tahun 2004-2005. Didapatkan penurunan $6 \%$ dari survei pertama sampai ketiga setelah dilaksanakan program DOTS. ${ }^{23}$ Selanjutnya Gopi dkk (2006) juga melaporkan hasil survei di India Utara, Barat, Selatan, dan Timur, pada 52.951 anak usia 1-9 tahun. Dilaporkan 32.744 anak telah mendapat vaksinasi BCG, dengan skar BCG positif. Prevalensi infeksi dan ARTI diperkirakan masing masing 5,4\% dan $1,0 \%$ pada anak dengan skar BCG positif, sedangkan pada anak tanpa skar BCG didapatkan hasil 5,9\% dan $1 \%{ }^{24}$ Hasil penelitian Gopi dkk (2008) di Chennai City, India, total subjek 7098 anak usia 1-9 tahun, hasil penelian mendapatkan BCG skar 0,5\% dengan ARTI 2,0\%. ${ }^{25}$ Penelitian lain dari Kerala, India pada 4821 anak usa 5-9 tahun, melaporkan $81 \%$ anak mempunyai skar BCG, 63,2\% ditemukan hasil uji tuberkulin $0 \mathrm{~mm}, 5 \%$ ukuran reaksi $\geq 10 \mathrm{~mm}, 3 \%$ reaksi $\geq 12 \mathrm{~mm}$, dan $\geq 14$ mm pada $2 \%$ anak. ${ }^{26}$
Pada tahun 2006 dilakukan penelitian untuk mengetahui angka ARTI pada anak yang dilakukan di Sumatera Barat. Berdasarkan pengamatan pada anak yang memiliki skar BCG dengan $16 \mathrm{~mm}$ sebagai cut offpoint dari pemeriksaan tuberkulin didapatkan angka prevalensi infeksi (95\% CI: 6,2-9,8\%) mencapai 8\% sehingga didapatkan nilai ARTI 1\%. Diperkirakan untuk setiap ARTI 1\%, rata-rata menunjukkan 96 kasus BTA positif TB per 100.000 populasi. ${ }^{27}$

\section{Faktor risiko}

Perkembangan TB pada manusia melalui dua proses, yaitu pertama seseorang yang rentan bila terpajan oleh kasus TB yang infeksius akan menjadi tertular TB (infectious TB), dan setelah beberapa lama kemudian baru menjadi sakit. Oleh karena itu faktor risiko untuk infeksi berbeda dengan faktor risiko menjadi sakit TB. ${ }^{28}$ Terdapat beberapa faktor yang mempermudah terjadinya infeksi TB maupun timbulnya penyakit TB pada anak. Faktor-faktor tersebut dibagi menjadi faktor risiko infeksi dan faktor risiko progresifitas infeksi menjadi penyakit (risiko penyakit).

\section{Risiko infeksi tuberkulosis}

Faktor risiko terjadinya infeksi TB antara lain adalah anak yang terpajan dengan orang dewasa dengan TB aktif (kontak TB positif), daerah endemis, kemiskinan, lingkungan yang tidak sehat (higiene dan sanitasi tidak baik), dan tempat penampungan umum (panti asuhan, penjara, atau panti perawatan lain), yang banyak terdapat pasien TB dewasa aktif. Sumber infeksi TB pada anak yang terpenting adalah pajanan terhadap orang dewasa yang infeksius, terutama dengan BTA positif. Berarti bayi dari seorang ibu dengan BTA sputum positif memiliki risiko tinggi terinfeksi TB. Semakin erat bayi tersebut dengan ibunya, semakin besar pula kemungkinan bayi tersebut terpajan percik renik (droplet nuclei) yang infeksius.

Risiko timbulnya transmisi kuman dari orang dewasa ke anak akan lebih tinggi jika pasien dewasa tersebut mempunyai BTA sputum positif, infiltrat luas atau kavitas pada lobus atas, produksi sputum banyak dan encer, batuk produktif dan kuat, serta terdapat faktor lingkungan yang kurang sehat terutama sirkulasi udara yang tidak baik. Pasien TB anak jarang 
Cissy B. Kartasasmita: Epidemiologi tuberkulosis

menularkan kuman pada anak lain atau orang dewasa di sekitarnya. Hal ini dikarenakan kuman TB sangat jarang ditemukan di dalam sekret endobronkial pasien anak. Beberapa hal yang dapat menjelaskan hal tersebut. Pertama, jumlah kuman pada TB anak pada umumnya sedikit (paucibacillary), tetapi karena imunitas anak masih lemah, jumlah yang sedikit tersebut sudah mampu menyebabkan sakit. Kedua, lokasi infeksi primer yang kemudian berkembang menjadi sakit TB primer biasanya terjadi di daerah parenkim yang jauh dari bronkus, sehingga tidak terjadi produksi sputum. Ketiga, tidak ada/sedikitnya produksi sputum dan tidak terdapatnya reseptor batuk di daerah parenkim menyebabkan jarangnya terdapat gejala batuk pada TB anak.

Penelitian mengenai faktor risiko untuk terjadinya infeksi TB di Gambia mendapatkan bahwa prevalensi uji tuberkulin positif pada anak laki laki dan perempuan tidak berbeda sampai adolesen, setelah itu itu lebih tinggi pada anak laki laki. Hal ini diduga akibat dari peran sosial dan aktivitas sehingga lebih terpajan pada lingkungan, atau karena secara bawaan lebih rentan, atau adanya faktor predisposisi terhadap respon hipersensitivitas tipe lambat. Selanjutnya kontak dengan pasien TB merupakan faktor risiko utama, dan makin erat kontak makin besar risikonya. Oleh karenanya kontak di rumah (household contact) dengan anggota keluarga yang sakit TB sangat berperan untuk terjadinya infeksi TB di keluarga, terutama keluarga terdekat. Faktor lain adalah jumlah orang serumah (kepadatan hunian), lamanya tinggal serumah dengan pasien, pernah sakit TB, dan satu kamar dengan penderita TB di malam hari, terutama bila satu tempat tidur. ${ }^{28}$

\section{Risiko sakit tuberkulosis}

Anak yang telah terinfeksi TB tidak selalu akan mengalami sakit TB. Berikut ini adalah faktor-faktor yang dapat menyebabkan berkembangnya infeksi TB menjadi sakit TB. Faktor risiko yang pertama adalah usia. Anak berusia $<5$ tahun mempunyai risiko lebih besar mengalami progresi infeksi menjadi sakit TB karena imunitas selularnya belum berkembang sempurna (imatur). Risiko sakit TB akan berkurang secara bertahap seiring dengan pertambahan usia. Pada bayi yang terinfeksi TB, $43 \%$ diantaranya akan menjadi sakit $T B$, pada usia $1-5$ tahun menjadi sakit $24 \%$, usia remaja $15 \%$, dan dewasa 5-10\%. Anak berusia $<5$ tahun memiliki risiko lebih tinggi mengalami TB diseminata (seperti TB milier dan meningitis TB), dengan angka morbiditas dan mortalitas yang tinggi. Risiko tertinggi terjadinya progresivitas dari infeksi menjadi sakit TB selama satu tahun pertama setelah infeksi, terutama selama 6 bulan pertama. Pada bayi, rentang waktu antara terjadi infeksi dan timbul sakit TB singkat (kurang dari 1 tahun) dan timbul gejala akut. Faktor risiko berikutnya adalah infeksi baru yang ditandai dengan adanya konversi uji tuberkulin (dari negatif menjadi positif) dalam satu tahun terakhir. Faktor risiko lainnya adalah malnutrisi, keadaan imunokompromais (misalnya pada infeksi HIV, keganasan, transplantasi organ, dan pengobatan imunosupresi), diabetes melitus, dan gagal ginjal kronik. Faktor yang tidak kalah penting pada epidemiologi TB adalah status sosioekonomi yang rendah, penghasilan yang kurang, kepadatan hunian, pengangguran, pendidikan yang rendah, dan kurangnya dana untuk pelayanan masyarakat. Di negara maju, migrasi penduduk termasuk menjadi faktor risiko, sedangkan di Indonesia hal ini belum menjadi masalah yang berarti. Faktor lain yang mempunyai risiko terjadinya penyakit TB adalah virulensi dari $M$. tuberkulosis dan dosis infeksi, namun secara klinis hal tersebut sulit untuk dibuktikan. ${ }^{6,28}$ Seperti telah disebutkan sebelumnya, keadaan imunokompromais merupakan salah satu faktor risiko penyakit TB. Pada infeksi HIV, terjadi kerusakan sistem imun sehingga kuman TB yang Borman mengalami aktivasi. Pandemi infeksi HIV dan AIDS menyebabkan peningkatan pelaporan TB secara bermakna di beberapa negara. Diperkirakan risiko terjadinya sakit TB pada pasien HIV dengan tuberkulin positif $7 \%-10 \%$ per tahun, dibandingkan dengan pasien non-HIV yang risiko terjadinya sakit TB 5\%-10\% selama hidupnya. Pada tahun 1990, 4,6\% kematian akibat TB disebabkan oleh infeksi HIV dan diperkirakan akan meningkat menjadi lebih dari 14\% pada tahun 2000. Angka kejadian TB yang telah menurun pada awal abad ke-20 kembali meningkat pada akhir tahun 1980. Hal tersebut terjadi bersamaan dengan meningkatnya epidemi HIV dan resistensi multiobat ( multi drug resistance $=\mathrm{MDR}$ ), bahkan sekarang sudah terjadi resistensi obat yang ekstrim (extreme drug resistance $=\mathrm{XDR})$.

\section{Daftar Pustaka}

1. World Health Organization (WHO). Guidance for national tuberculosis programme on the management of tuberculosis in children. WHO/HTM/2006.371. 
Cissy B. Kartasasmita: Epidemiologi tuberkulosis

2. World Health Organization (WHO). Childhood tuberculosis and BCG vaccine: EPI Update Supplement Geneva WHO, 1989.

3. Zar HJ, Hanslo D, Tannenbaum E. Aetiology and outcome of pneumonia in human immunodeficiency virus infected children hospitalized in South Africa. Acta Paediatr 2001;90:119-25.

4. Madhi SA, Petersen K, Madhi A, Khoosal M, Klugman KP. Increased disease burden and antibiot $5 i c$ resistance of bacteria causing severe community-aquired lower respiratory tract infections in human immunodeficiency virus type I infected children. Clin Infect Dis 2000; 31:170-6.

5. Chintu C, Mudenda V, Lucas S. Lung diseases at necropsy in African children dying from respiratory illnesses: a descriptive necropsy study. Lancet 2002;360:985-90.

6. Jeena PM, Pillay T, Coovadia HM. Impact of HIV-1 co-infection on presentation and hospital-related mortality in children with culture proven pulmonary tuberculosis in Durban, South Africa. Int J Tuberc Lung Dis 2002;6:672-8.

7. Madhi SA, Huebner RE, DoedensL, Aduc T, Wesley D, Cooper PA. HIV-1 co-infection in children hospitalized with tuberculosis in South Africa. Int J Tuberc Lung Dis 2000;4:448-54

8. Nelson LJ, Wells CD. Global epidemiology of childhood tuberculosis. Int J Tuberc Lung Dis 2004;8:636-47.

9. Graham SM, Gie RP, Schaaf HS, Coulter JBS, Espinal MA, Beyers N. Childhood tuberculosis: clinical research needs. Int J Tuberc Lung Dis 2004;8:648-57.

10. Departemen Kesehatan RI. Rencana strategi nasional penanggulangan tuberkulosis tahun 2002-2006. Jakarta: Departemen Kesehatan RI; 2001.

11. Departemen Kesehatan RI. Pedoman nasional penanggulangan tuberkulosis. Cetakan ke-8. Jakarta: Departemen Kesehatan Republik Indonesia; 2002.

12. Kochi A. The global tuberculosis situation and the new control strategy of the world health organization. Tubercle 1991;72:1-6.

13. Dolin PJ, Raviglione MC, Kochi A. Global tuberculosis incidence and mortality during 1990 -2000. Bull World Health Organ 1994;72:213-20.

14. Medical Research Council Tuberculosis and Chest Disease Unit (MRCT-CDU). Tuberculosis in children: a national survey of notifications in England and Wales in 1983. Arch Dis of Child 1988;63:266-76.

15. Kartasasmita CB, Said M, Supriyatno B. Penapisan dan pengobatan tuberkulosis pada anak sekolah dasar di Majalaya, Kabupaten Bandung. MKB 2001;3:105-12.
16. Kartasasmita CB. Childhood tuberculosis in the community. Disampaikan pada International Paediatric. Respiratory and Allergy Congress; Prague, Czech Republic 2001.

17. Rikesdas Indonesia tahun 2007. Laporan Hasil Riset Kesehatan Dasar. Departemen Kesehatan Republik Indonesia. Jakarta, 2008.

18. WHO 2004 WHO. TB/HIV a clinical manual. Edisi ke-2. Geneva: World Health Organization; 2004.

19. WHO-SEARO. Tuberculosis control in the South-East Asia Region. New Delhi, India: WE-- Regional Office for South-East Asia; 2003.

20. Peter R D. Childhood tuberculosis: the hidden epidemic. Int J Tuberc Lung Dis 2004;8:627-9.

21. Van Leth F, van der Wef MJ, Borgdorff MW. Prevalence of tuberculous infection and incidence of tuberculosis; a re-assessment of the Styblo rule. Bull WHO 2008;86:180.

22. Singh S, Chadha VK, Srivastava RK, Lakshminarayana, Magesh V, Suganthi P, Umadevi G, dkk. Prevalence and annual risk of tuberculosis infection among school children in Bangalore rural district. NTI Bulletin 2006;42/3\&4:68-73.

23. Gopi PG, Subramani R, Kolappan C, Prasad VV, Narayanan PR. Estimation of annual risk of tuberculosis infection among children irrespective of BCG scar in the south zone of India. Indian J Tuberc 2006;53:7-11.

24. Gopi PG, Subramani R, Narayanan PR. Trend in the prevalence of TB infection and ARTI after implementation of a DOTS programme in south India. Int J Tuberc Dis 2006;10:346-48.

25. Gopi PG, Prasad VV, Vasantha M, Subramani R, Tholkappian AS, Sargunan D, Nayanan PR. Indian J Tuberc 2008;55:157-61.

26. Kumar S, Radhakrishna, Chadha VK, Jeetendra R, Kumar P, Chauhan LS, Srivastava R, Umadevi, Kirankumar R. Prevalence of tuberculosis infection among school children in Kerala. Indian J Tuberc 2009;56:10-16.

27. Bachtiar A, Miko TY, Machmud R, Besral, Yudarini, Basri C, Mehta F, Chadha VK, Loprang F, Manissero D, Palupi KR, Jitendra R. Annual risk of tuberculosis infection in West Sumatra Province, Indonesia.Int J Tuberc Dis 2008;12:255-61.

28. Lienhardt C, Fielding K, Sillah J, Tunkara A, Donkor S, Manner K, Warndoff D, McAdam KP, Bennett S. Risk factors for Tuberculosis infection in Sub-Sahara Africa. Am J Respir Crit Care Med 2003;168:448-55. 